\title{
Jugular Foramen Neoplasm
}

National Cancer Institute

\section{Source}

National Cancer Institute. Jugular Foramen Neoplasm. NCI Thesaurus. Code C5589.

A neoplasm that affects the jugular foramen. Representative examples include

paraganglioma, schwannoma, and meningioma. 